\title{
The Role of NGOs in Supporting Education IN AFricA ${ }^{1}$
}

\author{
Michael Brophy \\ Independent Education Consultant
}

\begin{abstract}
Non-Government Organisations (NGOs) which support education in Africa may use different titles such as Council or Trust, are almost always Non-profit organizations. They differ in size, ranging from small local organisations through to large internal multinationals. When founded they will often reflect the ideas, objectives and views of their founders. Funds for new NGOs especially smaller organisations were, and still are, likely to come from supporters, small charities and foundations. Their activities are likely to focus either on specific areas for example village schools or supporting specific causes such as school children with disabilities. Funding for many NGOs has changed significantly from their early years. Many now receive large proportions of their funding from governments. However many NGOs perceive their work to be guided by the principals of neutrality and impartiality. Governments however may view the NGO education programmes they fund as being part of a "counter insurgency strategy" or as one of their "combat teams". Governments and international funders such as the European Union often now prefer to support consortia where a number of NGOs and multilateral organisations join together to work on a single project. There are significant benefits but also some significant problems.
\end{abstract}

Keywords: International Development; Fragile States; External Influence; Communities; Consortium

\section{NGOs: Purpose and Vision}

Many different non-governmental organizations (NGOs) support education in Africa; some NGOs such as Save the Children and OXFAM are large multinationals which cover the continent, employ hundreds of people and have annual budgets of tens of millions of British Pound Sterling ( $f$ ) (Save the Children UK, 2013; OXFAM, 2013). Others consist of a small number of volunteers helping to raising a few hundred pounds for a school in a particular village. NGOs also work under different titles such as association, charity, council, foundation, society or trust; generally however they share the common feature of being non-profit organizations. For most of the larger organizations education is only one part of their work along with other areas such as health, water and sanitation and child protection. Smaller NGOs are more likely to specialize in one area such as education, but even then they can be set up for different purposes and to meet different needs within education. Some, for example, may focus on pre-school or nursery education, some may provide small grants for university students and others may support the development of local languages).

The aims and focus of the work of NGOs are generally a reflection of the backgrounds and interests of those who have set up the organisation. Founders of an NGO are likely to set not only its aims and objectives but also its character and vision. However, as NGOs develop and grow, the question arises as to what extent will they be able to continue to follow their founders' aims and vision and to what extent will they have to adapt to changing needs, political situations and donor priorities. An example can be seen from the work of the Africa Educational Trust (AET), a medium sized NGO which has sixty years of experience working across Africa. Over that time, it has been

a Correspondence can be directed to: mgbrophy@btinternet.com 
able to manage and deliver a wide range of education programmes. Some were developed and delivered by the Trust, others were funded by governments either directly or as part of a consortium programme and developed by a government.

AET was set up by a group of people with different backgrounds, professions and political allegiances but with a shared interest and commitment to a particular cause - in this case helping people in Africa to prepare for and manage their countries' independence from colonialism. AET was established in 1958, almost two years before, but very much in tune with Harold Macmillan's famous 'Wind of Change' speech in which he spoke about the need to accept the awakening of national consciousness 'in peoples who had for centuries lived in dependence upon some other power' (Macmillan, 1960, p. 1).

Among those who helped to start AET were a publisher, a journalist, a number of academics and a priest. The priest, the Rev. Michael Scott was the prime mover in establishing the trust; some would say the instigator. Nelson Mandela described him as 'A great fighter for African rights'. Desmond Tutu wrote that 'He helped many of us black South Africans not to become antiwhite, for here was a white man who cared about us' (Yates \& Chester, 2006: Foreword). The US State Department called him 'A troublemaker' (Yates \& Chester, 2006) and MI5 the British Intelligence Agency reported that he had 'close communist party links' but also reported that the communists 'considered him to be "most peculiar" and under the influence of Quakers' (National Archives, 2014). Scott had already spent many years working in South Africa, initially in a leper colony and later in the black townships of Sophia and Tobruk. While in South Africa he became a prominent activist against the government's racial policies both in South Africa and in South-West Africa/Namibia. In 1949 he presented a petition on behalf of the people of South-West Africa to the UN against rule by South Africa. He continued to represent them at the United Nations for over thirty years. In 1952 when the South African government declared him a prohibited immigrant and banned him from entering the country, Scott returned to England and set up The Africa Bureau, an organization devoted to helping people in Africa gain independence for their country. The AET was formed six years later as an offshoot of the bureau. It was established specifically to help achieve the aims of the bureau by supporting education, mainly through scholarships in the UK. Michael Scott's view was that 'Education was the key to the development of a people' (Maxey, 1991; AET, 1998).

The backgrounds of AET's other founders were very different from Scott's. The first chair of the board of trustees, for example, had been educated at Eton and Oxford and had served as an officer in the British Army during the First World War. When AET was founded he was the director of the London School of Economics and vice chancellor of the University of London. As vice chancellor he had been responsible for establishing colleges and universities across Africa in countries such as Kenya, Nigeria, Sudan, Tanzania and Uganda. Another trustee had also been educated at Eton and Oxford and had been an intelligence analyst at the Bletchley Park code-breaking centre during the Second World War. Two of the founders had been born in Africa: one was the first Rhodes professor of race relations at the University of Oxford, the second the diplomatic editor of the Observer Newspaper.

The aims, approach and ethos of the organization that emerged were very much moulded and set by the founders and could be described as respectable, professional, left of centre politically and committed to working with people in Africa, especially those seeking independence and fairer government. It is not surprising therefore that one of first beneficiaries of the new NGO was Kenneth Kaunda who was supported to study economics while imprisoned in 1959 (Kaunda, 1963). Shortly afterwards in 1960 the first secretary of the AET, Joan Wicken left on a short leave of absence to help Julius Nyerere establish a college for adults in Tanzania. She remained as his personnel assistant for over thirty years. Joan was replaced by Pat Llewelyn-Davis a Labour Party activist who became a baroness in 1967 while still being the director of AET and later the first woman government chief whip in British history (Maxey, 1991; AET, 1998). 


\section{AET Liberation Movements and Scholarships}

The IUEF scandal had two major implications for NGOs. It reinforced and emphasized the need for confidentiality and security of information, especially on the location, courses and travel arrangements of students. However, it also brought about the closure of IUEF with the result that the Nordic governments rechanneled their funding though other like-minded organizations such as AET and WUS. The AET director during this period was Tim Matthews a Zimbabwean with close links to the Zanu party. The AET audited annual accounts from 1978 to 1981 reported that the funding AET received from the Nordic governments doubled over the four-year period. In its early years less than a quarter of the trust's scholarships (23 per cent) went to students from Southern Africa; by the late 1970 s and 1980 s this had risen to almost three quarters (73 per cent) (Unterhalter \& Maxey, 1996). This study also found that between 1958 and 1993 AET provided scholarships for over 1,600 students from Southern Africa, of these 49 per cent were from South Africa, 30 per cent from Zimbabwe, 19 per cent from Namibia and 2 per cent from other Southern Africa countries.

It is worth noting that the change in direction and emphasis was not a policy decision made by the NGO but one brought about by changes in donor funding policies, specifically the decision by the Nordic governments to fund Southern Africa liberation movements and their later reaction to the IUEF scandal. It was during the 1970s and 1980s that AET made its greatest contribution towards support for education in Southern Africa. For most of that time it was one of the very few organizations providing scholarships for members of the liberation movements. The tracer study found that two-thirds of the beneficiaries had strong connections with the ANC or other movements including the Pan African Congress and Black Consciousness Movement. Three quarters of the beneficiaries had returned or were planning to return to Southern Africa. The study noted that the 'AET South African Programme clearly succeeded in helping to produce a highly educated and competent group of people, the majority of whom are making a very significant contribution to the political, economic and cultural development of South Africa in its current transition from apartheid' (Unterhalter \& Maxey, 1996, p. 9).

Among those traced were government ministers, members of parliament, senior government administrators, lawyers, medical doctors, dentists, engineers, university professors and teachers. There were similar results from a tracer study of AET's former scholarship holders from Namibia where 90 per cent of those traced had returned to Namibia and were in employment (Preston \& Kandando, 1992). AET Southern African scholarship holders have gone on to become cabinet ministers and university vice chancellors in South Africa, Namibia and Zimbabwe. They also include the current chair of the Africa Union and the union's commissioner for social affairs.

\section{Adapting to Change in Southern Africa}

From 1990 onwards Nordic donors' policies towards Southern Africa began to change. Zimbabwe had gained its independence in 1980. What had been a major scholarship programme in the 1960s and 1970s ended in the mid-1980s as donors channelled their funds through the new Zimbabwean government rather than international NGOs. The war in Namibia ended in 1988 and again donor policies changed to providing direct funding to the new government. When Nelson Mandela was released from prison in February 1990 it was clear that donor policies towards South Africa itself were also going to change.

The trust had been successful in managing scholarships for Southern African students to study in the UK for over thirty years and like other organizations such as WUS and the Canon Collins Educational Trust for Southern Africa it was now faced with the question of whether or not there was still a role for NGOs such as AET when independent governments were in place across Africa and donors could fund them directly. The trust's first response was to continue with scholarships in the UK but move the focus from Southern Africa to the Horn Region where there was still ongoing 
conflict. This approach worked for a time. AET had received limited funding for students from the Horn from 1983 and the Nordic donors were prepared to continue and increase it. However, with the ending of the Ethiopian Civil War in 1991 and new governments in both Ethiopia and Eritrea, donors' policies once again shifted towards direct government funding.

Not all of the AET's trustees had agreed with the change in geographic focus to the Horn Region and a number resigned. New trustees not linked to Southern Africa were appointed. In a major development for the trust three of these new appointments were women. Shortly afterwards there was also a change in the style of directorship. From 1958 to 1992, AET's directors had generally come from political backgrounds. Since 1993 the directors appointed have had backgrounds in education and development.

AET scholarship programmes had humanitarian as well as developmental aims (Brophy, Bird \& Omona, 1997). With the change in donors' policies one approach it adopted was to seek funding from the UK Home Office and local authorities for education and training programmes to help refugees settle in the UK. A second approach was to continue with scholarship programmes but for study in African universities. A problem with this second approach was that by the 1990s donors were not only stopping funding for overseas scholarships, but they were cutting back generally on support for higher education.

\section{Education and Rates of Return}

Since the mid-1970s there had been a growing interest among the international community in the rates of return from investments in education. Surveys for the World Bank had reported that there was a much greater rate of return from investment in primary education than from secondary or tertiary. Figures suggested that in Africa investment in higher education gave a social rate of return of 12 per cent or less, secondary a return of 17-18 per cent while in primary education it gave a return of 25-29 per cent (Psacharopoules, 1981, 1994; Psacharopoules \& Patrinos, 2002). Although the figures were highly controversial and were criticized among other things for flawed methodology (Knight, Sabot \& Hovey, 1992) and economic assumptions (Bloom, Canning \& Chan, 2005), the concept was accepted by the World Bank and by most UN agencies and governments. It was fundamental to the development of both the Education for All (EFA) and the Millennium Development goals (MDGs) and the subsequent focus on primary education. It also led to major falls in funding for higher education. The World Bank's own funding for higher education as percentage of its education sector funding fell from 17 per cent in 1985 to 1989 to 7 per cent in 1995 to 1999 (Bloom, Canning \& Chan, 2005).

Organizations which had provided scholarships in Europe were faced with a double dilemma. They and their staff may have had many years of experience working in higher education but had very limited or perhaps no experience of working at the primary level and their experience and professional knowledge were of the UK and European education sectors; they had limited or again no experience of working in Africa. Where possible organizations fell back on their reserves while they attempted to reorient and restructure themselves. In some cases this meant selling offices and moving into smaller rented accommodation. Other organizations were unsure of what strategy to adapt, work in the UK with refugees and asylum seekers or work overseas at the primary level. Some like AET and WUS adapted a duel approach, continuing working with refugees in the UK while building a capacity to work overseas. This duel approach although successful created tension within organizations and often led to employment tribunals as longer serving UK scholarship staff saw themselves as being squeezed out.

Although income fell year on year the majority of AET's funding in this period was for work in the UK. It included funding from local authorities and foundations for research, advisory work and study grants for refugees and asylum seekers. This was important for the trust as the first projects in Africa were slow in coming with some potential donors rejecting proposals because of AET's lack of experience of working either in Africa or in primary education. The first project in Africa came in 
1996 after the Somaliland minister of education met with one of the new trustees, Professor loan Lewis. It led to a joint project with the University of Manchester for a capacity-building programme for education staff in Somaliland and was funded by the UK Overseas Development Administration (now DFID). It was soon followed by grants from the European Union and Comic Relief for work with primary schools in Southern Sudan and in 1997 a grant from the Norwegian government for scholarships and training programmes for Southern Sudanese students in Africa. Norwegian government support for this programme continued for twelve years and through it a large cohort of Southern Sudanese gained qualifications in areas key for reconstruction and development. They included almost 200 students who studied by distance learning for qualifications in public administration and management while continuing to live and work in South Sudan (FHIG, 2004).

\section{Meeting Needs but Whose Needs?}

The trust's experience of working with liberation movements meant that it was better able and more comfortable than most organizations working in conflict areas. One question faced by the trustees and staff, now the trust was working in Africa, was whose needs should it try to meet in conflict-affected areas - needs as expressed by children and parents or those expressed by local authorities and governments or needs as identified by donors and multilateral agencies. A study of the role of NGOs in four African states has reported that 'governments generally believe that it is their legitimate right and responsibility to control everything that happens in their country. Although government personnel often talk about partnerships with NGOs, they believe that the relationship should be government regulating NGOs' (AED, 2002, p. 6).

While governments and international organizations might argue that they were all aiming to meet the same needs, they often had different views on what these were. In the 1990s there was an ongoing debate in the international community around the concept of what were called fragile states or conflict affected countries. While the primary aim of aid for these states was developmental there was a growing awareness in the West that long-term conflict in countries such as Iraq, Afghanistan, Sudan and Somalia could affect their own security and had the potential to promote terrorism. Providing aid, including support for education, was viewed as one way of protecting a country's own interests. The former British prime minister Gordon Brown has referred to education projects as part of the 'hearts and mind' activities within a counter insurgency strategy while Colin Powell the former US secretary of defence referred to NGO staff as being 'an important part of our combat team' in conflict areas (Colenso, 2012, p. 64). For NGOs working in the field it was difficult to reconcile these government and donor's views with the historical concept of humanitarian aid being based on principles of neutrality and impartiality.

Local authorities and governments in fragile states also often had different views from donors and UN agencies on what were the needs of children and young people in their communities. Even the word 'needs' raised issues for them. Local authorities and governments were familiar with the idea of developing programmes to meet children's educational needs. They were unfamiliar with the concept of developing them to meet children's rights. Yet often donors, UN agencies and NGOs focused on programmes which used a 'Rights Based' approach (UNICEF, 2004; Council of the European Union, 2014). A multidisciplinary, cross-sectorial child rights-based approach was seen by many international organizations as being essential for coordination with governments. Unfortunately it could lead to government staff being unwilling to attend coordination and planning meetings and rather than being actively involved in these, ministries were sometimes simply made 'aware of the partners' meeting agenda items and of the main outcomes of meetings' (Aguilar, 2012, p. 99).

A second difficulty for the local governments and authorities was that fragile states almost by definition had weak institutional capacities. Developing local capacity and infrastructure to manage and deliver education programmes was a priority for local administrations, but they felt these were often not a priority for donors and NGOs, which they saw as concentrating on beneficiary numbers rather than developing sustainable systems (McNerney, 2005). However, while local government 
capacity remained weak, donors, even if they wished to develop this, preferred to work through UN agencies and NGOs which they felt could make better progress than governments in improving education (Benn, 2007 in Colenso, 2012, p. 64). There was also a view that reconstruction of education systems in conflict situations provided an opportunity for major changes that the local governments and authorities may not necessarily agree with

For education and reform and transformation, the post-conflict reconstruction environment is the best of times and the worst of times, both an opportunity and a constraint. It is the best of times because the post-conflict reconstruction environment offers significant opportunities for policy reform and system change. (Buckland, 2005, p. 25).

These views were not limited to education and were held in other areas such as health, sanitation and transport and could lead to what local people perceived as parallel governments running their country with NGOs being seen as being tools of the donor governments (AED, 2002). In places such as Somalia and South Sudan this perception was reinforced by donors and NGOs use of a zonal approach, through which different NGOs were funded to deliver education or health programmes in specific geographic areas or zones, usually from within their own NGO-enclosed compounds - an approach which for local people was reminiscent of the former colonial systems of administration.

AET's experience, however, was that in contrast to central authorities and local governments, parents and communities in fragile states often agreed with donors bypassing central administrations. Inequalities in the provision of education had often been an underlying cause of conflict and were perceived by parents as being due to corruption at the central level. However, parents and local communities were less likely to agree with donors and NGOs over the type of education their children should receive. Like those in central administrations parents and local communities had little or no understanding of the concept of children's rights. They wanted their children, especially their sons, to be educated so that they could earn money. Education was a means of a family escaping from poverty (Bekalo, Brophy \& Welford, 2000).

For donors and NGOs there was also an inherent tension in the delivery of education projects between the need to disburse funds efficiently and effectively and the need to reach the poor and disadvantaged. At one extreme there were large-scale 'capital intensive' projects, building schools, supplying materials and equipment and printing textbooks. From a donor's viewpoint these met an obvious need and evidence can be produced that they were successful, buildings were built and text books and materials produced and delivered. Expenditure could be justified and results shown. It was also relatively easy to spend a large proportion of the aid budget quite effectively. The problem was that such projects had difficulty reaching the poor particularly in rural areas (Karpinska, 2012). The local governments were more likely to want NGOs to work with marginal populations and communities on the periphery and in areas which were more difficult and expensive to reach (AED, 2002). Smaller non-formal education programmes they felt could reach the poor and disadvantaged. They also had the advantage that they paid teachers and provided incentives across a much wider social and geographic range and so funds could be seen to be spread more equitably across society. However, it was more difficult for NGOs to provide evidence to donors of success and impact for these non-formal and rural programmes or to identify and isolate the effects of a particular activity or intervention (AET, 2011b; Karpinska, 2012).

\section{Working with the Community}

Between 1996 and 2005 AET concentrated on developing new and innovative ways of providing basic and non-formal education programmes for disadvantaged children and young people particularly those living in rural areas. Within this work there was a strong focus on promoting gender equity and a commitment to working with and through local communities and organizations and also with 
regional and national authorities. As a demonstration of its commitment to this approach the trust opened local offices across Southern Sudan, Somalia and Uganda, all of which were managed by local staff. There was also a regional office in Kenya staffed predominantly by Kenyans. Distance learning was one of the innovative approaches AET used to help provide education to young people who were unable to access education through formal schooling. The largest such programme was the joint AET and BBC World Service, Somali Distance Education for Literacy (SOMDEL) project, through which over 100,000 young Somalis who had missed out on formal education were able to complete basic education courses and receive education certificates from their ministries. Many SOMDEL classes took place in rural and nomadic communities and were taught at times and locations suited to the needs and situations of the community. Of those who benefited 75 per cent were girls and young women (Brophy \& Page, 2007). A World Bank report referred to the SOMDEL programme as being 'one of the World's most innovative uses of distance learning to reach uneducated populations in conflict situations' (World Bank, 2006, p. 1).

A second example of an AET innovative project during this period was the School Baseline Assessment (SBA) programme for Southern Sudan which was developed in partnership with United Nations International Children's Emergency Fund (UNICEF). This programme trained local teachers and educationalists to assess over 1,400 schools across Southern Sudan and established the first computer database of primary schools in Southern Sudan (AET-UNICEF, 2003). It was widely used by multilateral and bilateral government agencies and donors for planning support for education after the 2004 comprehensive ceasefire.

Although SOMDEL, SBA and other AET projects such as the school mothers and street children programmes in Uganda and nomadic education programmes in Kenya and Somalia were innovative and relatively important for the impact they had, they were still quite small. In 1998 the average annual funding for an AET project was less than $f 10,000$ per year. By 2004 although this had increased to an average of $£ 50,000$ per year, the projects were still relatively small. Organizations such as AET were finding that even in fragile states, bilateral and multilateral donors were becoming less willing to support projects developed by NGOs in partnership with local governments and communities. In both education and other areas, in order to improve coordination and reduce duplication and at the same time reduce their own staffing and administration costs, donors were moving towards large countrywide approaches.

Donors today are being held to account very closely for the funds they disburse. Many key humanitarian donors are finding economies of scale by funding NGO consortia to respond to emergencies or to work on finding solutions to common challenges as a group. This enables a wider reach with potentially more limited resources. By forming a strong and effective country-level consortium, NGOs position themselves well vis-à-vis their donors to receive support for their efforts. (ECB, 2013, p. 7)

These large programmes, however, often had aims, goals and objectives developed by public servants and fund managers and based more on global and international strategies and targets than on local or beneficiaries perceptions of needs.

\section{Donors and Consortia}

Once more NGOs were faced with a dilemma should they continue as they were with relatively small programmes developed in close consultation with beneficiaries and local communities but not necessarily in line with donor governments' interests and priorities or should they work within a consortium to reach a greater number of beneficiaries through programmes based on internationally agreed goals and standards (Graham, 2010; Kweyu, 2013). The choice was difficult for in addition to helping greater numbers of people large grants also helped to cover staff salaries and administration, logistics and transport costs. Things which were problematic when there was only funding for small 
projects. Large projects also often allowed staff to travel, monitor and deliver project activities across a larger area. However, for smaller and medium NGOs the question arose as to whether or not they still had ownership of their activities and projects. Were they partners or simply contractors? Some larger NGOs also felt the pressure to combine with partners in consortium and larger groupings. Describing the formation of Save the Children's Global Challenge, Webley reported how 2003 was a turning point for the different Save member organizations as they accepted that 'it was clear that the world needed fewer, stronger NGOs' and that for 'corporate survival' they had to 'either combine or compete' (Webley, 2012, p. 74).

There were a few exceptions in the push towards consortia; in 2004 the president of Somaliland made a direct request to the British government for assistance in establishing a national examinations centre. The UK government was unwilling to support the Somaliland Education Ministry directly. However, AET had a good working relationship with the ministry and was asked by the minister to prepare and submit a proposal for support for the centre. The proposal was approved by UK Department for International Development (DFID) and a grant was made for support to the ministry through AET. This examinations programme was an important milestone for both Somaliland and for AET and involved a grant which totalled over $£ 3$ million (Page, 2010; AET, 2010b). It also reinforced and strengthened the trust's relationship with the ministry. Two years later when the European Union invited bids from the consortia for a programme to support secondary education in Somalia the ministry supported the bid of the consortium led by AET which was successful.

The idea of a consortium approach was already familiar in the private sector and in higher education but not that well known within the NGO community. The idea of four or more international organizations joining together to bid for and manage a large donor-funded project was a relatively new concept not only for AET but for many NGOs. Graham has suggested that multi-agency consortium applications for donor funding only really started in 2006 (Graham, 2010). From 2008 onwards AET continued to work in South Sudan. Kenya and Uganda either on their own or with a single partner, but in Somalia due to changing donor policies most of its work there began to be carried out in consortium with other organizations. Funding from these consortium projects was significantly higher than the funding for the non-consortium projects. In 2010, for example, the trust's annual accounts showed that AET's income from a single EU-funded consortium programme in Somalia, Strengthening Access and Participation in Secondary Education (SAPIS), was 1.5 times the combined income from its six largest projects in South Sudan. In fact although AET supported thirty-nine projects that year, 42 per cent of its income came from just three consortium projects (AET, 2010a).

Working within consortia may have meant reducing duplication and being able to help significantly more children and young people access education, but consortia also had their own problems and difficulties. For organizations like AET the major problems almost always related to finance and the financial structure within the consortium. In a traditional project structure the NGO received its funding directly from the donor; within a consortium the funds could pass through two or three other organizations before reaching the NGO. This meant that often there were frequent and lengthy delays in the receipt of funds. When this happened NGOs had to use their reserves to ensure that staff were paid and project activities kept going. The problems were magnified when organizations were involved in more than one consortium which meant that there could be a constant strain on its reserves and cash flow with negative effects on staff moral and the organization's standing with the ministry and local communities. Delays were also likely to have a 'carry over' effect with later tranches of funds being held up while lead organizations waited on each partner collecting receipts and invoices from the field, preparing and submitting accounts. The time between spending one tranche of funding and receiving the next was often determined by the capacity and skills of whichever organization within the consortium had the weakest finance department.

A second financial problem stemmed from a common donor requirement that NGOs provide a share of the funding for a programme, commonly known as matched funding. Bilateral and multilateral donors were under pressure from governments to ensure that they obtained value for money from their programmes and there was a growing pressure and expectation by donors 
that NGOs should reduce their costs (Graham, 2010). One way to achieve this was by requiring organizations to bring additional funding to a programme. Instead of covering all planned expenditure the donor would offer only a proportion and require partner organizations to provide the balance. In a competitive situation the more matched funding a consortium could offer the more likely it was to receive the contract. As the budgets of consortium programmes grew so did the amounts required for matched funding with smaller partners often experiencing pressure from both the donor and the lead organization to increase contributions and reduce administration costs. This could lead to a concern among the partners that the lead organizations were trying to 'cream off' all of the money (Cabinet Office, 2008). Matched funding of $£ 25,000$ for a single project was feasible for most smaller NGOs. Raising 10 or 20 per cent of $£ 10$ million was much more problematic even if there were a number of partners. Foundations and charities were and are also generally reluctant to see their funds being used and absorbed into large government or multilateral programmes rather than being directed at smaller discrete projects they can feel some ownership of.

Finance and financial management were not the only problems that NGOs encountered as they learned to work in consortia. Difficulties familiar from single project management were often exacerbated by the increased length of the management chain in a consortium where there were ample opportunities for misunderstanding and different interpretations between and within the multiple levels of management. There were also greater restrictions on developing and trying innovative approaches and on adapting to changing local needs. For example, when there were fresh outbreaks of fighting in countries such as Somalia and South Sudan, AET and other smaller organizations by working through local staff were able to continue their projects in areas not affected by the outbreak. Consortium programmes were much more likely to be shut down, generally on instructions from the donor or funding government.

NGOs also quickly realized that large consortia programmes just like projects had limited lifespans (Kweyu, 2013). In small- and medium-sized organizations local staff rarely worked on a single project and when one project ended it was possible to continue employing them until new ones could be started. Employing people on a longer term basis meant that they were more likely to understand and be committed to the work and mission of the organization. It also meant that the organization had experienced staff in place and was ready to start new programmes quickly. Consortia programmes required full-time staff and their own separate running costs. When they ended after two or three years it was rarely possible for smaller organizations to cover or absorb these continuation costs. On large consortia programmes staff understood they were likely to be made redundant at the end of the cycle and often started looking for new jobs well before the end of the programme (People in Aid, 2010). NGOs found themselves looking for temporary, lessexperienced staff for the last months of programmes. With a high turnover of staff NGOs were less likely to invest in capacity building and staff training.

Large organizations are likely to be better able to absorb staff and office costs in interim periods and in providing matched funding. They are also likely to have larger finance departments. Consortium programmes have continued to grow in size with donors inviting bids for programme grants of many millions of dollars. Recent examples were the UK Department for International Development (DFID) 2012 Girls Education South Sudan (GESS) programme with a budget of $f 50$ million over six years (DFID, 2012) and the USAID South Sudan Safer Schools Support Project with a budget of US\$105 million over five years (USAID, 2012). As they have grown consortium programmes have increasingly favoured the structures and resources of larger organizations and those who are better able to cope with the risks and the liability (Cabinet Office, 2008; Kweyu, 2013).

\section{Conclusion}

When it was established in 1958 the AET closely reflected the views and interests of its founders by supporting higher education scholarships for people from Africa and helping to develop the capacity and skills needed by people in newly independent countries. Throughout its history the trust has 
continued to support students from Africa, but there have been major changes both in how and in where it has worked. For more than half of its existence it focused on scholarships in the UK mainly for students from Southern Africa. In the 1990 s as the political situation and donor priorities changed, AET adapted and most of its work became focused on providing further and higher education grants to African refugees living in the UK. By 2000 , however, it had once more adapted to meet changing priorities and concentrated on supporting primary and non-formal education programmes in Africa.

From this review of its history and activities it is clear that AET has made an important and significant contribution to education in Africa. It is also clear that throughout its existence it has been able to adapt to changing situations and priorities. Currently like many other NGOs it is faced with having to adapt from working on individual projects it has developed in partnership with local communities and authorities to working as a partner in large consortium programmes where most of the assessment and planning have already been carried out by the donor and fund managers. For AET and many similar organizations the question has arisen once again of how to maintain a balance between achieving its own vision and aims and adapting to the changing priorities of governments and agencies.

As the 2002 Academy for Educational Development (AED) study of the 'Role of NGOs in Basic Education in Africa' has noted donors finance NGO education activities because they share similar priorities, goals and policies: 'When they diverge, donors are easily able to leverage a realignment' (AED, 2002, p. 31). However, as that report has cautioned 'donors can be fickle and may abandon an NGO if their interests shift' (AED, 2002, p. 35).

\section{Note}

1 This article is an updated and edited version from Education and NGOs (2016), London: Bloomsbury Academic

\section{References}

AED (2002). Evolving Partnerships: The Role of NGOS in Basic Education in Africa, Support for Analysis and Research in Africa (SARA) Project. Washington, DC: Academy for Educational Development.

AET (1998). A Brief History and Background to the Work of AET 1958-98. London: Africa Educational Trust.

AET/UNICEF (2003). School Baseline Assessment Report South Sudan. London: Africa Educational Trust.

AET (2010a). Annual Report and Accounts. London: Africa Educational Trust.

AET (2010b). The Impact of Donor Support to National Examination Systems in Somalia and Somaliland. London: Africa Educational Trust.

AET (2011a). Scholarship/Grants, Kenneth Kirkwood Fund and Andrzejewski Memorial Fund. London: Africa Educational Trust.

AET (2011b). Empowering Village Education, Improving Enrolment and Retention of Girls in Primary Schools in South Sudan. London: Africa Educational Trust.

Africa National Congress (1961). International University Exchange Fund: Its Rise and Demise. Available at: http://www.anc.org.za/show.php?id=6867\&1 [Accessed 3 February 2014].

Agee, P. (1991). CIA Infiltration of Student Groups, The National Student Association Scandal. Campus Watch, Fall 1991, pp. 12-13.

Aguilar, P. (2012). Coordination: Education and the IASC Cluster Approach in the Ivory Coast. In Z. Karpinska (Ed.) Education, Aid and Aid Agencies. London: Continuum. pp. 90-112.

Bekalo, S., Brophy, M. \& Welford, A.G. (2000). Flexible Approaches to Education in Sub-Saharan Africa: Improving Access and Retention, Education Policy and Strategy. London: DFID.

Bloom D., Canning, D. \& Chan, K. (2005). Higher Education and Economic Development in Africa Harvard University, USA. Available at: http://http://ent.arp.harvard.edu/AfricaHigherEducation/ Reports/BloomAndCanning.pdf [Accessed 2 February 2014]. 
Brophy, M., Bird, P. \& Omona, M. (1997). Vocational Training for Refugees from the Horn of Africa: An Evaluation and Review. London: AET.

Brophy, M. \& Page, E. (2007). Radio literacy and life skills for out-of-school youth in Somalia. Journal of International Cooperation in Education, 10(1), pp. 135-147.

Buckland, P. (2005). Reshaping the Future, Education and Post Conflict Reconstruction. Washington, DC: World Bank.

Cabinet Office (2008). UK Government, Working in a Consortium: A Guide for Third Sector Organisations Involved in Public Service. London: Office of the Third Sector.

Colenso, P. (2012). Donor Policies: The Evaluation and Development of DFID's Commitment to Education in Fragile States (2000-10). In Z. Karpinska (Ed.) Education, Aid and Aid Agencies. London: Continuum. pp. 51-70.

Council of the European Union (2014). Council Conclusions on a Rights-Based Approach to Development Co-operation, Encompassing All Human Rights. Brussels: Foreign Affairs (Development) Council Meetings.

DFID (2012). Business Case for the Girls Education South Sudan (GOSS) Programme. London: DFID.

Dorril, S. (2002). MI6: Inside the Covert World of Her Majesty's Secret Intelligence Service. New York: Free Press.

ECB (2013). Emergency Capacity Building Project: What We Know about Collaboration: The ECB Country Consortium Experience. Available at: http://www.ecbproject.org/consortium/guide/ [Accessed 17 August 2014].

FHIG (2004). Fort Hare Institute of Government, Evaluation Report on NORAD - Africa Educational Trust (AET) Scholarship Programme for Southern Sudanese 1999-2004. Alice, South Africa: Fort Hare University.

Graham, R. (2010) The Consortium Approach to Resource Mobilisation and Human Resource Development: Sight Savers. Available at: https//www/lapb.org/Sites/Sightsavers_Insightplus _June2010 [Accessed 17 August 2014].

Herbsten, D. (2004). White Lies, Canon Collins and the Secret War against the Apartheid. Oxford and Cape Town: James Curry and HSRC Press.

Karpinska, Z. (2012). Education, Aid and Aid Agencies. London: Continuum.

Kaunda, K. (1963). Zambia Shall Be Free. London: Heinemann Books.

Knight J., Sabot R., and Hovey, D. (1992). Is the rate of return of primary education really 26 per cent? Journal of African Economies, 1(2), pp. 192-205.

Kweyu, B. (2013). The Somalia Cash Consortium, Lessons Learnt from a Consortium Approach, Cash Transfers in South Central Somalia, Danish Refuge Council. Available at: https//drc.dk/ fileadmin/uploads/pd/nyheder_PDF/cash-consortium-Lessons-Learnt-Study-January-2013pdf [Accessed 17 August 2014].

Macmillan, H. (1960). Wind of Change. Available at: http://www.famous-speeches-and -speechtopics.info/famous-speeches/harold-macmillan-speech-wind-of-change.htm [Accessed 30 January 2014].

McNerny, F. (2005). Final Evaluation ABEC Afghanistan. Amherst: Centre for International Education, University of Massachusetts.

Maxey, K. (1991). The Contribution of the Scholarship Programme of the Africa Educational Trust to African Development: A Brief History of the Africa Educational Trust 1958-91. London: AET.

Moore, D. (2005). Zanu-PF and the ghost of foreign funding. Review of Africa Political Economy, 32(103), pp. 156-162.

National Archives (2014). MI5 Documents Relating to Michael Scott KV2/2052 and KV2/2052. Available at: http://www.nationalarchives.go.uk/records/ [Accessed 20 February 2014].

Oxfam (2013). Oxfam Annual Report 2012-2013. Oxford: OXFAM

International. Page, E. (2010). A Study of the Purposes Behind the Somaliland Secondary Exams and the Implications, if any, for Fragile States. Unpublished Masters Dissertation, Institute of Education, University of London. 
People in Aid (2010). Addressing Staff Retention and Improving Staff Engagement. People in Aid Capacity Building Project Horn of Africa Consortium Project. London: People in Aid.

Preston, R. \& Kandando, D. (1992). The Situation AET-Sponsored Namibians after Their Return Home. Windhoek: University of Namibia.

Psacharopoulos, G. (1981). Returns to investment in education: An updated comparison. Comparative Education, 17 (3), pp.321-341.

Psacharopoulos, G. (1994). Returns to investment in education: A global update. World Development, 22(9), pp.1325-1343.

Psacharopoulos, G. \& Patrinos, H.A. (2002). Returns to Investment in Education: A Further Update, Latin America and Caribbean Region. Washington, DC: World Bank.

Save the Children (2013). Leave No Child Behind, Annual Report for 2013. London: Save the Children.

Sellstrom, T. (1999). Sweden and National Liberation in Southern Africa, Vol 1 1950-1970. Uppsala: Nordiska Afrikainstitut.

Sellstrom, T. (2004). Retrospectives on Official Swedish and Nordic Support to the Anti-Apartheid Struggle. Available at: www.docstoc.com/docs/49851832/celebrating-the [Accessed 29 January 2014].

UNICEF (2004). The Human Rights Approach, Annex B, The State of the World's Children. Washington: UNICEF.

Unterhalter, E., Maxey, K. et al. (1996). Educating South Africans in Britain and Ireland. London: AET and IOE, University of London.

USAID (2012). Funding Opportunity RFA-668-13-000001, USAID South Sudan Safer Schools Support (SS) Project in South Sudan. Washington, DC: USAID.

Webley, K. (2012). Leadership: Save the Children's Global Challenge. In Z. Karpinska (ed.) Education, Aid and Aid Agencies. London: Continuum. pp. 71-89.

World Bank (2006). Somalia from Resilience towards Recovery: A Countrywide Economic Memorandum for Somalia. Washington, DC: World Bank.

Yates, A. and Chester, L. (2006). The Troublemaker. London: Aurum Press. 